\title{
PAP smear in pregnancy: a hospital-based study
}

\author{
S. Senthil Priya ${ }^{1 *}$, R. Shankar ${ }^{2}$ \\ ${ }^{1}$ Department of Obstetrics and Gynecology, ${ }^{2}$ Department of Preventive Medicine, VMKVMCH, Salem, Tamil Nadu,
} India

Received: 17 September 2018

Accepted: 22 October 2018

\section{*Correspondence:}

Dr. S. Senthil Priya,

E-mail: senthilpriya2000@gmail.com

Copyright: (c) the author(s), publisher and licensee Medip Academy. This is an open-access article distributed under the terms of the Creative Commons Attribution Non-Commercial License, which permits unrestricted non-commercial use, distribution, and reproduction in any medium, provided the original work is properly cited.

\section{ABSTRACT}

Background: Pregnant and non-pregnant women are at similar risk for CIN and cervical cancer. The incidence of abnormal cervical cytologic findings during pregnancy is 0.72 to $1.67 \%$. Approximately $86 \%$ of all squamous intraepithelial lesions (SIL) indentified during pregnancy are classified as low-grade SIL, whereas $14 \%$ are highgrade SIL. The aim of this study is to assess the incidence of Pap smear abnormalities among antenatal woman presenting to present hospital.

Methods: A prospective study was conducted in present medical college hospital in the department of Obstetrics and Gynecology for a period of one year from Jan 2017 to Dec 2017. A total of 200 antenatal women were included in the study. Ayre's spatula was used to conduct smear tests in this study. All smears were immediately sprayed with a fixative and sent to the department of Pathology. The cytological results were reported based on the Bethesda classification system 2001.

Results: The pap smear report revealed that $26 \%$ of the subjects had inflammatory changes and for $66 \%$ it showed negative for intraepithelial lesion and for only $1 \%$ of the subjects had signs related to carcinoma cervix in which one patient had Atypical Squamous Cell of Undetermined Significance (ASCUS) and another patient had Low-grade Squamous Intraepithelial Lesion (LSIL) and no satisfactory sample was able to be obtained in 6\% of the subjects. In present study authors found a statistically significant association between the age at marriage and the pap smear report, lower the age at marriage ( $<20$ years) higher the incidence of inflammatory changes in the cervix and both the patients who were reported with ASCUS and LSIL were in the age of 15 and 16 years respectively.

Conclusions: Clinicians should make every effort to educate, counsel and screen pregnant women if they have not had a Pap test in the past.

Keywords: Antenatal women, Cervical cancer, Pap smear

\section{INTRODUCTION}

Cervical cancer is one of the three most common malignant processes, among females, worldwide. ${ }^{1}$ Every year, more than 493,000 individuals are diagnosed with and 274,000 die from cervical cancer, worldwide. The majority of these cases $(80 \%)$ are experienced in developing countries. ${ }^{2}$ The peak incidence of this disease is found in women in their third decade, which is also the time of the maximal childbearing capacity.
Concomitantly, there has been an increased frequency of cervical intraepithelial neoplasia (CIN) in pregnancy. Pregnant and non-pregnant women are at similar risk for CIN and cervical cancer. ${ }^{3}$ There is no significant difference in the incidence of CIN between pregnant and nonpregnant women (0.82 vs $0.46 \%)$. CIN occurs on an average in 1.3 per 1000 pregnancies $(0.6-3.23 / 1000){ }^{4}$ Generally, the majority of the pregnant women with CIN have CIN 1 or other evidence of HPV infection. CIN 3 is comparatively less common among pregnant females. 
The analysis of epidemiological data shows that disease has been detected during the pregnancy or postpartum period in 1.7 to $3.1 \%$ of all patients with invasive cervical cancer. ${ }^{5}$ The incidence of abnormal cervical cytologic findings during pregnancy is 0.72 to $1.67 \%$. Approximately $86 \%$ of all squamous intraepithelial lesions (SIL) identified during pregnancy are classified as low-grade SIL, whereas $14 \%$ are high- grade SIL. ${ }^{5}$

High-risk human papilloma virus (HPV) is the cause of cervical cancer. It is a curable disease if early detection and precancerous lesion is timely treated. Given the high number of women seeking prenatal care and the close follow up provided during this period, pregnancy and prenatal care offer an excellent opportunity to implement the cervical cytology test for premalignant condition in young age group patients. ${ }^{6}$

A clinical difficulty is that the normal changes of the cervix during pregnancy can in many ways mask a cancer and the malignancy may thus be missed if not multiple or large biopsies are taken. ${ }^{7}$ Invasive interventions on the cervix may increase the risk of bleeding, secondary to the increased vascularity during pregnancy, and increased risks for obstetrical complications may also be present. ${ }^{8}$ Conventional Pap smear is the standard method for cervical cancer screening.

Pap test detects $60-70 \%$ of cancer cervix and $70 \%$ of endometrial cancer. The accuracy of pap smear in pregnancy is almost similar to that of non-pregnant women. Pap smear in pregnancy is useful to screen more number of women in reproductive age group. ${ }^{9}$ As of today only very few studies had been conducted in assessing the incidence of abnormal pap smear during pregnancy period and so the present study was undertaken in detecting the abnormal pap smear among the antenatal females.

\section{METHODS}

A prospective study was conducted in present medical college hospital in the Department of Obstetrics and Gynecology for a period of one year from January 2017 to December 2017.

\section{Inclusion criteria}

- All the antenatal women reporting to present department in the age group between 18 and 40 years were included for the study.

The study was started after obtaining the clearance from the institutional ethical committee.

\section{Exclusion criteria}

- Although collecting a smear in pregnancy has not shown to pose any risk to the fetus, women with the history of threatened, abortion, miscarriage and placenta previa in the present pregnancy may be reluctant to undergo a pap smear. Hence, they are excluded from the study.

A total of 200 antenatal women were included in the study. Informed consent was obtained from all the study subjects. A pre-tested questionnaire was used to obtain the patients demographic details and obstetrics profile. The smear test was carried out once information of a PAP smear test was provided, and consent was obtained. After emptying the bladder, patient was put in lithotomy position.

Cusco's speculum is introduced into the vagina and the cervix was visualised. Ayre's spatula was used to conduct smear tests in this study. All smears were immediately sprayed with a fixative and sent to the department of Pathology. The cytological results were reported based on the Bethesda classification system 2001.

Abnormal results were defined as atypical squamous/ glandular cells or more which include atypical squamous cell of undetermined significance (ASC-US), atypical squamous cell cannot exclude HSIL (ASC-H), low-grade squamous intraepithelial lesion (LSIL), high-grade squamous intraepithelial lesion (HSIL), atypical glandular cell not otherwise specified (AGC-NOS), atypical glandular cell favor neoplasia (AGC-FN), adenocarcinoma in situ (AIS), adenocarcinoma and squamous cell carcinoma (SCCA). Patients who had abnormal results were informed and referred to a gynecologic oncologist.

\section{Statistical analysis}

All data were entered and analysed using SPSS version 22. Mean and standard deviation was derived for all the parametric variables. Chi-square test was used to find any association between categorical variables considering $\mathrm{p}<0.05$ to be statistically significant.

\section{RESULTS}

The age wise distribution of the study subjects was shown in Table 1. It is seen from the table that majority of the study subjects were in the age group between 20 and 25 years with a minimum age of 18 years and the maximum age was 41 years and the mean age was 22.6 years.

Table 1: Age wise distribution of the study subjects.

\begin{tabular}{|c|c|c|c|}
\hline Age group & Frequency & Percentage & Mean \pm SD \\
\hline$<20$ & 12 & 6 & \multirow{7}{*}{$22.6 \pm 4.8$} \\
\hline $20-25$ & 122 & 61 & \\
\hline $26-30$ & 45 & 22.5 & \\
\hline $31-35$ & 12 & 6 & \\
\hline $36-40$ & 7 & 3.5 & \\
\hline$>40$ & 2 & 1 & \\
\hline Total & 200 & 100 & \\
\hline
\end{tabular}


Most of present study subjects were primi (42.5\%) followed by $2^{\text {nd }}$ gravida $(37.5 \%)$ and only $7 \%$ of present study subjects were in the 4 th gravida (Table 2).

Table 2: Distribution of the study subjects based on their parity status.

\begin{tabular}{|lll|}
\hline Gravida & Frequency & Percentage \\
\hline Primi & 85 & 42.5 \\
\hline Two & 75 & 37.5 \\
\hline Three & 26 & 13 \\
\hline Four & 14 & 7 \\
\hline Total & 200 & 100 \\
\hline
\end{tabular}

Gestational age for majority of the study subjects was between 16 and 25 weeks with a mean gestational age of 28.6 weeks and the maximum gestational age of present study subjects was 33 weeks (Table 3 ).

Table 3: Distribution of the study subjects based on their gestational age.

\begin{tabular}{|c|c|c|c|}
\hline $\begin{array}{l}\text { Gestational age } \\
\text { (in weeks) }\end{array}$ & Frequency & Percentage & Mean \pm SD \\
\hline $5-10$ & 28 & 14 & \multirow{7}{*}{$28.6 \pm 8.8$} \\
\hline $11-15$ & 22 & 11 & \\
\hline $16-20$ & 37 & 18.5 & \\
\hline $21-25$ & 38 & 19 & \\
\hline $26-30$ & 34 & 17 & \\
\hline$>30$ & 44 & 22 & \\
\hline Total & 200 & 100 & \\
\hline
\end{tabular}

The most common finding of the per speculum examination was healthy cervix which was observed in
$89 \%$ of the antenatal mother's and $10 \%$ of them had eroded cervix and for $1 \%$ of the subject's growth was seen in the cervix (Table 4).

Table 4: Distribution of the study subjects based on the per speculum examination.

\begin{tabular}{|lll|}
\hline Per speculum results & Frequency & Percentage \\
\hline Healthy cervix & 178 & 89 \\
\hline Erosion of cervix & 20 & 10 \\
\hline Growth & 2 & 1 \\
\hline Total & 200 & 100
\end{tabular}

The pap smear report revealed that $26 \%$ of the subjects had inflammatory changes and for $66 \%$ it showed negative for intraepithelial lesion and for only $1 \%$ of the subjects had signs related to carcinoma cervix in which one patient had Atypical Squamous Cell of Undetermined Significance (ASCUS) and another patient had Lowgrade Squamous Intraepithelial Lesion (LSIL) and no satisfactory sample was able to be obtained in $6 \%$ of the subjects (Table 5).

Table 5: Distribution of the study subjects based on the Pap smear report.

\begin{tabular}{|lll|}
\hline Pap smear report & Frequency & Percentage \\
\hline NIL & 132 & 66 \\
\hline Inflammatory changes & 54 & 26 \\
\hline No satisfactory sample & 12 & 6 \\
\hline ASCUS & 1 & 0.5 \\
\hline LSIL & 1 & 0.5 \\
\hline Total & 200 & 100 \\
\hline
\end{tabular}

Table 6: Distribution of the study subjects based on their age at marriage and the Pap smear report.

\begin{tabular}{|lllllll|}
\hline Pap smear report & $\mathbf{2 0}(\mathbf{n = 7 3})$ & $\mathbf{2 1 - 2 5}(\mathbf{n = 7 6})$ & $\mathbf{2 6 - 3 0}(\mathbf{n = 3 2})$ & $\mathbf{3 1 - 3 5}(\mathbf{n = 1 2})$ & $>\mathbf{3 5}(\mathbf{n = 7})$ & P value \\
\hline NIL & $26(35.6 \%)$ & $63(82.8 \%)$ & $28(87.5 \%)$ & $9(75 \%)$ & $6(85.7 \%)$ & 0.281 \\
\hline Inflammatory changes & $41(56.1 \%)$ & $10(13.1 \%)$ & $2(6.2 \%)$ & $1(8.3 \%)$ & 0 & $<0.001$ \\
\hline ASCUS & $1(1.3 \%)$ & 0 & 0 & 0 & 0 & $<0.001$ \\
\hline LSIL & $1(1.3 \%)$ & 0 & 0 & 0 & 0 & $<0.001$ \\
\hline No enough sample & $4(5.4 \%)$ & $3(3.9 \%)$ & $2(6.2 \%)$ & $2(16.6 \%)$ & $1(14.2 \%)$ & 0.389 \\
\hline
\end{tabular}

In present study authors found a statistical significant association between the age at marriage and the pap smear report, lower the age at marriage ( $<20$ years) higher the incidence of inflammatory changes in the cervix and both the patients who were reported with ASCUS and LSIL were in the age of 15 and 16 years respectively.

Mother's with age more than 20 years majority of them had a report of negative for intraepithelial lesion (NIL) (Table 6). So, in present study authors found only age at marriage as the significant risk factor for developing carcinoma cervix and none of present study subjects had any other risk factors like smoking or multiple sex partners.

\section{DISCUSSION}

The Pap smear test used as a screening method to detect cervical cancer is an effective way to prevent the development of cervical cancer, but awareness within the community about the Pap smear test is very low. 
According to the American Cancer Society, the Pap smear test is a routine cancer screening method that should be done every 3 years, and a Pap smear with an HPV DNA test is recommended as a screening method every 5 years. ${ }^{10}$ In past studies the prevalence of abnormal cervical cytology in pregnancy varied from one to another. For example, Yamazaki et al reported $1.13 \%$ in Japan, 2006, and in Thailand, the reported prevalence was $0.8 \%$ in $2005,0.52 \%$ in 2008 and $7 \%$ in $2010 .{ }^{11-14}$ The prevalence of abnormal Pap smear in pregnancy is dependent on the population undergoing screening and could be as high as 5-8\%.15 Pregnancy creates an important opportunity to screen the cervix for neoplastic and infectious diseases, and pick up the disease in early stage will increase. ${ }^{16}$ In present study $1 \%$ of the screened pregnant women showed abnormal Pap test result and it was in par with the previous studies conducted by Manikkam B where she found abnormal Pap test in $1 \%$ of pregnant women studied and in which $0.5 \%$ of the smear showed abnormality and diagnosed as ASCUS which is similar to present study. ${ }^{17}$ Comparably Vural et al found ASCUS in $1.55 \%$ of the pregnant women screened. This indicates an increasing rate of abnormal cervical cytology, which will lead to an increase in incidence of invasive cancer without an adequate screening programme. ${ }^{18}$ In the study conducted by Yatl et al, had shown that $0.086 \%$ of pregnant women had ASC-US, $0.049 \%$ had SIL (HPV compatible), and $0.012 \%$ had invasive cervical carcinoma. ${ }^{19}$ A study conducted by Ayten Dinc on Turkish women had revealed ASC-US was detected in $0.9 \%$ of pregnant cases and $3.5 \%$ of non-pregnant cases, and LGSIL was detected in $1.2 \%$ of non-pregnant cases. ${ }^{20}$ Another study done by Khaengkhor et al on 143 pregnant women had identified 10 abnormal PAP smear test results; four cases had ASCUS, five cases had LSIL, and one case had HSIL and almost a similar type of results was also shown in the study done by Fan et al on 11,506 pregnant women. ${ }^{21}$

In present study the inflammatory changes were reported in $26 \%$ of the subjects. Other studies reported $95 \%$ and $74.5 \%$ had inflammation indicated by the Pap smear test, respectively. ${ }^{22,23} \mathrm{~A}$ few studies reported that women with persistent inflammation should be appropriately treated; otherwise, the chance of development of cervical intraepithelial lesions increases. ${ }^{24,25}$

Present study had an unsatisfactory report rate of $6 \%$, which might have been due to dryness of the smear or a technical error. The $4.8 \%$ unsatisfactory report rate reported by Vaghela et al might have been due to proper training of personnel and the use of the proper technique. $^{26}$ The present study had shown that the abnormal pap smear was more common in women who had married at a very early age and this was similar to the results showed by Himabindu et al in their study. ${ }^{27}$

Pap smear should be performed at the first prenatal visit regardless of the duration of pregnancy to establish the presence or absence of SIL, STD, and BV, all of which represent a risk to the fetus and the mother. This initial smear will establish a baseline diagnosis and can be followed up accurately throughout pregnancy by repeated Pap smears. ${ }^{28,29}$ Although pregnancy does not significantly alter the rates of false-negative results in general, several common physiologic changes associated with pregnancy can cause difficulties in interpretation of a Papanicolaou smear. Examples of these effects include the increasing levels of estrogen and progesterone which lead to hyperplasia of the cervical glands that creates mucus plug. This endocervical mucus becomes thick and tenacious in pregnancy coupled with an increase in vaginal secretions overall, visibility of the cervix may be hampered. $^{30}$ Conducted studies prove that cervical cytology conducted during pregnancy is as reliable as those conducted when the individual is not pregnant. ${ }^{18} \mathrm{~A}$ Norwegian study showed that Pap smear screening during pregnancy increases the 10 coverage of the cervical cancer screening programme. ${ }^{31}$

\section{CONCLUSION}

Clinicians should make every effort to educate, counsel and screen pregnant women if they have not had a Pap test in the past. Pregnancy is the period during which a woman definitely seeks medical care and antenatal clinics provide opportunities for screening. In a country like India where organised screening programmes are not available, as well as the awareness and uptake of available services by the target population is also poor, screening in pregnancy is worthwhile and may be a viable option to reduce the burden of cervical carcinoma.

Funding: No funding sources Conflict of interest: None declared

Ethical approval: The study was approved by the Institutional Ethics Committee

\section{REFERENCES}

1. Ferlay J, Bray F, Pisani P. GLOBOCAN 2002. Cancer incidence, mortality and prevalence Worldwide. IARC Cancer Base No. 5. Version 2.0, IARC Press, Lyon.

2. Parkin DM, Bray F, Ferlay J, Pisani P. Global cancer statistics, 2002. CA Cancer J Clin. 2005;55(2):74108.

3. Fader AN, Alward EK, Niederhauser A. Cervical dysplasia in pregnancy: a multinational evaluation. Am J Obstet Gynecol 2010;203:113.e1-6.

4. Katyal S, Mehrotra R. Complementary procedures in cervical cancer screening in low resource settings. J Obstet Gynecol India. 2011;61(4):436-8.

5. Cronje HS, van Rensburg E, Niemand I, Cooreman BF, Bever E, Divall P. Screening for cervical neoplasia during pregnancy. Int $\mathbf{J}$ Gynecol Obstet. 2006;6:19-23.

6. Brown D, Berran P, Kaplan KJ. Special situations: abnormal cervical cytology during pregnancy. Clin Obstet Gynecol. 2005;48:178-85. 
7. Economos KA, Perez NV, Delke IS, Collado ML, Tancer ML. Abnormal cervical cytology in pregnancy: a 17-year experience. Obstet Gynecol. 1993;81(6):915-8.

8. Nygard JF, Nygard M, Skare GB, Thoresen SO. Pap smear screening in women under 30 in the Norwegian coordinated cervical cancer screening program, with a comparison of immediate biopsy vs Pap smear triage of moderate dysplasia. Acta Cytol. 2006;50(3):295-302.

9. Hunter MI, Monk BJ, Tewari KS. Cervical neoplasia in pregnancy. Part 1: screening and management of preinvasive disease. Am J Obstet Gynecol. 2008;199(1):3-9.

10. Saslow D, Solomon D, Lawson HW, Killackey M, Kulasingam SL, Cain J, et al. American Cancer Society, American Society for Colposcopy and Cervical Pathology, and American Society for Clinical Pathology screening guidelines for the prevention and early detection of cervical cancer. CA Cancer J Clin. 2012;62:147-72.

11. Yamazaki $T$, Inaba $F$, Takeda $N$, Huruno $M$, Kamemori T, Kousaka N, et al. A study of abnormal cervical cytology in pregnant women. Arch Gynecol Obstet. 2006;273:274-7.

12. Sueblinvong T, Suwannarurk K, Chanthasenanont A, Treetampinich C, Pongrojpaw D. Prevalence and management of abnormal pap smear in antenatal care clinic at Thammasat University Hospital. J Med Assoc Thai. 2005;88:133-7.

13. Ngaojaruwong N, Vuthiwong C, Punpuckdeekoon $P$, Thongsorn N. Prevalence of abnormal papanicolaou smear in pregnant women at Phramongkutklao Hospital. Thai J Obstet Gynaecol. 2008;16:179-85.

14. McDonald SD, Faught W, Gruslin A. Cervical cancer during pregnancy. J Obstet Gynaecol Can. 2002;24:491-8.

15. Economos K, Perez Veridiano N, Delke I. Abnormal cervical cytology in pregnancy: a 17 - year experience. Obstet Gynecol. 1993;81:915-8.

16. Arbyn M, Autier P, Ferlay J. Burden of cervical cancer in the 27 member states of the European Union: estimates for 2004. Ann Oncol. 2007;18(8):1423-5.

17. Manikkam B. Screening for cervical cancer during pregnancy. Int $\mathrm{J}$ Community Med Public Health. 2016;3:2493-8.

18. Vural E, Gonenc L, Aka N. Antenatal kontrollerde pap smear taraması ve Sonucları. Türkiye Aile Hekimligi Dergisi. 2004;8:111-5.

19. Yatlı S, Altıntepe G, Dayıcioglu V. Gebelerde servikal kanser taraması. Zeynep Kamil Tıp Bülteni. 2003;34:7-11.
20. Ayten Dinc. Pap Smear Screening Results for Turkish Pregnant Women. Asian Pacific Journal of Cancer Prevention.2012;, Vol 13(11)5835-38.

21. Khaengkhor $P$, Mairaing $K$, Suwannarurk $K$, Thaweekul Y, Poomtavorn Y, Pattaraarchachai J, et al. Prevalence of abnormal cervical cytology by liquid based cytology in the antenatal care clinic, Thammasat University Hospital. J Med Assoc Thai. 2011;94:152-8.

22. Atilgan R, Celik A, Boztosun A, Ilter E, Yalta T, Ozercan R, et al. Evaluation of cervical cytological abnormalities in Turkish population. Indian J Pathol Microbiol. 2012;55:52-5.

23. Kulkarni PR, Rani H, Vimalambike MG, Ravishankar S. Opportunistic screening for cervical cancer in a tertiary hospital in Karnataka, India. Asian Pac J Cancer Prev. 2013;14:5101-5.

24. Bhutia K, Puri M, Gami N, Aggarwal K, Trivedi SS. Persistent inflammation on pap smear: Does it warrant evaluation?. Indian J Cancer. 2011;48:220-2.

25. Barouti E, Farzaneh F, Sene A. The pathogenic microorganism in papanicolaou vaginal smears and correlation with inflammation. J Family Reprod Health. 2013;7:23-7.

26. Vaghela BK, Vaghela VK, Santwani PM. Analysis of abnormal cervical cytology in papanicolaou smears at tertiary care center-A retrospective study. IJBAR. 2014;5:47-9.

27. Himabindu P, Kanwal A, Vasudha MS. Pap smear in antenatal women - routine screening in low resource settings. IOSR J Dent Med Sci. 2015;14(4):4-5.

28. Apgar BS, Kittendorf AL, Bettcher CM, Wong J, Kaufman AJ. Update on ASCCP consensus guidelines for abnormal cervical screening tests and cervical histology. Am Fam Physician. 2009;80(2):147-55.

29. Ueki M, Ueda M, Kumagai K, Okamoto Y, Noda S, Matsuoka M. Cervical cytology and conservative management of cervical neoplasias during pregnancy. J Low Genit Tract Dis. 2009;13(3):182-5.

30. Connor JP. Noninvasive cervical cancer complicating pregnancy. Obstet Gynecol Clin North Am. 1998;25:331-42.

31. Nygård $M$, Daltveit $\mathrm{AK}$, Thoresen $\mathrm{S} \varnothing$, Nygård JF. Effect of an antepartum Pap smear on the coverage of a cervical cancer screening programme: a population-based prospective study. BMC Health Serv Res. 2007;7(1):10.

Cite this article as: Priya SS, Shankar R. PAP smear in pregnancy: a hospital based study. Int J Reprod Contracept Obstet Gynecol 2018;7:4924-8. 